\title{
Quis custodiet ipsos custodes? Assessing the systems of controls of the European Fisheries Control Agency's inspecting powers
}

Citation for published version (APA):

Cacciatore, F., \& Eliantonio, M. (2020). Quis custodiet ipsos custodes? Assessing the systems of controls of the European Fisheries Control Agency's inspecting powers. In M. Scholten, \& A. Brenninkmeijer (Eds.), Controlling EU Agencies: The Rule of Law in a Multi-jurisdictional Legal Order (pp. 215-233). Edward Elgar Publishing. https://doi.org/10.4337/9781789905427.00020

Document status and date:

Published: 01/01/2020

DOI:

10.4337/9781789905427.00020

\section{Document Version:}

Publisher's PDF, also known as Version of record

\section{Document license:}

Taverne

\section{Please check the document version of this publication:}

- A submitted manuscript is the version of the article upon submission and before peer-review. There can be important differences between the submitted version and the official published version of record. People interested in the research are advised to contact the author for the final version of the publication, or visit the DOI to the publisher's website.

- The final author version and the galley proof are versions of the publication after peer review.

- The final published version features the final layout of the paper including the volume, issue and page numbers.

Link to publication

\footnotetext{
General rights rights.

- You may freely distribute the URL identifying the publication in the public portal. please follow below link for the End User Agreement:

www.umlib.nl/taverne-license

Take down policy

If you believe that this document breaches copyright please contact us at:

repository@maastrichtuniversity.nl

providing details and we will investigate your claim.
}

Copyright and moral rights for the publications made accessible in the public portal are retained by the authors and/or other copyright owners and it is a condition of accessing publications that users recognise and abide by the legal requirements associated with these

- Users may download and print one copy of any publication from the public portal for the purpose of private study or research.

- You may not further distribute the material or use it for any profit-making activity or commercial gain

If the publication is distributed under the terms of Article $25 \mathrm{fa}$ of the Dutch Copyright Act, indicated by the "Taverne" license above, 


\section{Quis custodiet ipsos custodes? Assessing the systems of controls of the European Fisheries Control Agency's inspecting powers}

Federica Cacciatore and Mariolina Eliantonio ${ }^{1}$

\section{INTRODUCTION. THE EUROPEAN FISHERIES CONTROL AGENCY'S OVERALL MISSION AND TASKS}

The European Fisheries Control Agency (EFCA) is an EU agency based in Vigo. Established by Regulation 768/2005, recently codified in Regulation $2019 / 473^{2}$ (hereinafter, Regulation 473), following an agreement of 2002, its

1 This chapter is a result of a common undertaking. However, Section 2 and Subsections 3.1, 3.2 and 3.3 can be directly attributed to Federica Cacciatore; Section 1 and Subsections 3.4 and 3.5 can be directly attributed to Mariolina Eliantonio; finally, Sections 3 and 4 contain common reflections.

2 Regulation (EU) 2019/473 of the European Parliament and of the Council of 19 March 2019 on the European Fisheries Control Agency (codification), OJ L 83. The former baseline regulation was Council Regulation (EC) 768/2005 of 26 April 2005 establishing a European Fisheries Control Agency and amending Regulation (EEC) 2847/93 establishing a control system applicable to the common fisheries policy, OJ L 128. The regulation was amended twice. First, by Council Regulation (EC) 1224/2009 of 20 November 2009 establishing a Community control system for ensuring compliance with the rules of the common fisheries policy [...], OJ L 343, in the context of the new control regime for the CFP, and then by Regulation (EU) 2016/1626 of the European Parliament and of the Council of 14 September 2016 amending Council Regulation (EC) 768/2005 establishing a Community Fisheries Control Agency, OJ L 251, to increase EU cooperation on coast guard functions and to strengthen cooperation between EFCA, the European Maritime Safety Agency (EMSA) and the European Border and Coast Guard Agency (Frontex). For more on this, see F. Cacciatore, M. Eliantonio, 'Fishing in troubled waters? Shared enforcement of the Common Fisheries Policy and accountability gaps', in M. Scholten, M. Luchtman (eds.), Law Enforcement by EU Authorities. Implications for Political and Judicial Accountability, Cheltenham, Edward Elgar Publishing, 2017, 168-194. See also S. Eliasen, T. Hegland, J. Raakjar 
main mission is 'to promote the highest common standards for control, inspection and surveillance under the Common Fisheries Policy (CFP)'. ${ }^{3}$ Later, Regulation $1224 / 2009^{4}$ (hereinafter, Control Regulation) established a Union control system for ensuring compliance with the rules of the CFP.

Before an autonomous and comprehensive CFP was adopted, fisheries were regulated within the Common Agricultural Policy (CAP), launched in 1962. ${ }^{5}$ It was in 1983 that a first step towards a CFP was taken. ${ }^{6}$ From then on, the CFP was increasingly developed, and growing regulatory powers previously in the hands of Member States were shifted to the EU level. They were mainly aimed at establishing fishing standards and maximum quotas to safeguard biodiversity and competitiveness. Nevertheless, while rules were established at the EU level, often they were not satisfactorily implemented at the national level, either because regulatees were not compliant or because Member States did not properly oversee how these rules were complied with. ${ }^{7}$ Therefore, a quest for stronger control over the CFP effectiveness emerged, ${ }^{8}$ which led to major policy reforms. ${ }^{9}$ In particular, the Commission issued a Green Paper ${ }^{10}$ containing its proposals for the reform of the CFP. Among these was the introduction

(2015), 'Decentralising: the implementation of regionalization and co-management under the post-2013 Common Fisheries Policy', Marine Policy, 62: 224; M. Salomon, T. Markus, M. Dross (2014), 'Masterstroke or paper tiger - the reform of the EU's Common Fisheries Policy', Marine Policy, 47: 76; J. Wakefield, Reforming the Common Fisheries Policy, Cheltenham, Edward Elgar Publishing, 2016.

3 https://www.efca.europa.eu/en/content/objectives-and-strategy.

4 See note 2 above.

5 See https://ec.europa.eu/info/food-farming-fisheries/key-policies/common -agricultural-policy/cap-glance_en.

6 Cacciatore and Eliantonio (note 2 above) $168 \mathrm{ff}$.

7 T. Gray, J. Hatchard (2003), 'The 2002 reform of the Common Fisheries Policy's system of governance - rhetoric or reality?', Marine Policy, 27(6): 545-554; J.-M. DaRocha, S. Cerviño, S. Villasante (2012), 'The Common Fisheries Policy: an enforcement problem', Marine Policy, 36(6): 1309-1314. For an overview of the different outcomes of the CFP throughout the EU, see M. Hadjimichael, G. Edwards-Jones, M.J. Kaiser (2010), 'Distribution of the burden of fisheries regulations in Europe: the north/ south divide', Marine Policy, 34: 795-802.

8 W. Battista, R.P. Kelly, A. Erickson, R. Fujita (2018), 'Fisheries governance affecting conservation outcomes in the United States and European Union', Coastal Management, 46(2): 388-452.

9 C. Johnson (2008), 'Fisheries enforcement in European Community waters since 2002 - developments in non-flag enforcement', The International Journal of Marine and Coastal Law, 23: 249-270; D. Symes (2009), 'Reform of the European Union's Common Fisheries Policy: making fisheries management work', Fisheries Research, 100(2): 100 .

${ }_{10} \operatorname{COM}(2001) 135$ final, 'Green Paper on the future of the common fisheries policy’, Brussels, 20/03/2001. 
of a decentralized enforcement system, according to which powers should be delegated to the lowest competent level of governance, ${ }^{11}$ and the establishment of an EU-level ad hoc agency, with coordinating powers over the control and inspection activities within the CFP. The agency, formerly named Community Fisheries Control Agency (later renamed European Fisheries Control Agency (EFCA)), was established in 2005 by Regulation 768/2005 and was attributed the main task to 'coordinate control and inspection by Member States relating to the control and inspection obligations of the Community'. ${ }^{12}$ Its competences were further enlarged in $2009,{ }^{13}$ especially in the field of on-site inspections, thus taking a further step towards verticalization of enforcement powers, as well as regulatory ones. After that, in 2012-2013, another major revision provided the regions with more effective powers in the CFP's implementation phase. ${ }^{14}$

As already mentioned, the primary role of EFCA is to coordinate the control and inspection operations and foster cooperation among Member States in order to improve the implementation of and compliance with the CFP.

EFCA carries out various tasks in the field of fisheries and, in order to achieve its goals, it is endowed with different types of powers. First, there are advisory powers towards the Commission in regulatory matters when it comes to fisheries-related issues. Second, there are enforcement powers, in that it may conduct, on the one hand, direct inspections of Union fishing vessels outside Union waters, according to Article 79 of the Control Regulation, by means of Union inspectors and, on the other hand, it may ensure operational coordination between the EU and the Member States, in relation to information sharing, assistance, and inspecting activities related to the Specific Control and Inspection Programmes (SCIPs) which the Commission sets up in the sphere of fisheries. Third, EFCA also plays a key role in setting up the Joint Deployment Plans (JDPs), the main implementing tool for SCIPs; and, finally,

11 In 2002 a Regulation was adopted with this aim (Council Regulation 2371/2002 on the conservation and sustainable exploitation of fisheries resources under the Common Fisheries Policy, OJ L 358). On the benefits of regionalization, see also H. Österblom, M. Sissenwine, D. Symes, M. Kadin, T. Daw, C. Folke (2011), 'Incentives, social-ecological feedbacks and European fisheries', Marine Policy, 35: 568-574; J. Raakjær (2011), 'The EU Common Fisheries Policy - a fisheries management system that has failed!', Acta Agriculturae Scandinavica, Section C - Food and Economics, 8(2): 105-113.

12 Art. 3(a) of Regulation 473.

13 Council Regulation 1224/2009 establishing a Community control system for ensuring compliance with the rules of the common fisheries policy, OJ L 343.

14 Regulation 1379/2013 on the Common organisation of the markets in fishery and aquaculture products, OJ L 354. For more info, see Salomon, Markus, Dross (note 2 above) $76-84$. 
it supports the EU and national actors in research and development in the area of fisheries.

In this chapter, we will focus on EFCA's inspection-related competences, which are of various types and involve different actors (EU and national), with a view to analysing the system of controls therein. This analysis is based on the relevant legislative provisions as well as on reports and other documents by EFCA itself and the Commission.

\section{EFCA'S INSPECTION-RELATED POWERS}

Inspections play a fundamental role in order for the EU to keep control over policy implementation and the degree of compliance with it. In the case of fisheries, inspection powers are shared between the European and national level, in the typical 'web' of relationships characterizing the system of 'shared administration'. ${ }^{15}$ EFCA, previously charged with mostly coordinating functions, nowadays also enjoys shared enforcement powers. ${ }^{16}$

Regarding its inspection-related tasks, according to Regulation 473, EFCA carries out the following activities: (a) coordination of and assistance in national inspections; (b) training and coordination of inspectors; (c) direct inspections; (d) inspection operations involving third countries. These aspects are described in detail below, where the role played by the other EU and national relevant actors is also scrutinized where relevant. At the end of the section, these findings are summarized in Table 12.1.

\subsection{Coordination of and Assistance in National Inspections}

Pursuant to Article 3 of Regulation 473, EFCA is in charge of coordinating and controlling inspections which Member States carry out under the CFP (Article 3(a)); it also coordinates the deployment of national means of control and inspections (Article 3(b)). The Agency also assists Member States in reporting information related to the inspections to the Commission and third parties

\footnotetext{
15 See on this concept e.g. J.H. Jans, S. Prechal, R. Widdershoven (eds.), Europeanisation of Public Law, 2nd edn, Groningen, Europa Law Publishing, 2015.

${ }_{16}$ Among shared enforcement powers (Cacciatore and Eliantonio, note 2 above), we may distinguish a sub-category represented by networked powers, consisting of more collaborative forms of enforcement between Member States and the EU authorities, which may not always be structured and operating pursuant (only) to legal norms, nor do they always involve an active role for traditional EU institutions or for the ad hoc agencies. See further F. Cacciatore and M. Eliantonio (2019), 'Networked enforcement in the Common Fisheries Policy through data sharing: Is there room left for traditional accountability paradigms?', European Journal of Risk Regulation, 10(3): 522.
} 
(Article 3(c)) and assists Member States to fulfil their tasks and obligations pursuant to the rules of the CFP (Article 3(d)).

In particular, whereas the Commission establishes the SCIPs in the CFP framework in cooperation with Member States in accordance with Article 95 of Regulation 1224/2009, EFCA is attributed, according to Articles 5 and 10 of Regulation 473, the key task of implementing them through the adoption of JDPs, whose content is laid down in Article 11 of Regulation 473. Currently there are four JDPs: Mediterranean and Eastern Atlantic (adopted in 2014 and involving nine countries), Baltic Sea, North Sea (both operating since 2007 and both involving eight countries) and Western Waters (established in 2012 and concerning 12 countries). ${ }^{17}$

Pursuant to its task to 'assist Member States' as they carry out their tasks under the CFP, EFCA's members also participate in joint inspections conducted according to the JDPs, playing a coordinating role. ${ }^{18}$

EFCA may also be requested to take up coordinating tasks in those fisheries or fishing areas which are not subject to a SCIP: Article 16 of Regulation 473 establishes that two or more Member States may agree to ask for such coordination of their means of control and inspection, according to criteria and priorities previously agreed between the countries concerned. An example is the recent operational plan named 'Black Sea', in force since 2012, to provide specific assistance to Bulgaria and Romania for joint inspection and control activities of turbot fisheries in the Black Sea. ${ }^{19}$

\subsection{Training and Coordination of Inspectors}

Besides its coordinating functions, EFCA is also endowed with training functions for national and Union inspectors. Article 3 of Regulation 473 specifies that the Agency must contribute to the coordination of inspector training and the exchange of experience between Member States (Article 3(g)), and to research and development activities in that field (Article 3(f)). Article 7 lists a series of specific tasks within EFCA's overall assistance role, among which are the establishment and development of a core curriculum for the training of the instructors of the fisheries inspectorate of the Member States and of the EU inspectors and provision of 'additional training courses and seminars to

\footnotetext{
17 More information is available on EFCA's website: https://www.efca.europa.eu/ en/content/joint-deployment-plans-eu-waters.

18 See, for example, EFCA (2019), Annual Report 2018, Vigo, European Fisheries Control Agency: 152 (about EFCA's participation in the JDP Mediterranean during 2018).

19 For further details, see https://www.efca.europa.eu/en/content/other -coordination. See also ibid., 19.
} 
those officials and other personnel involved in control and inspection activities'. EFCA may also, on request from the Commission or Member States, develop common inspection methodologies and procedures and draw up joint operational procedures in relation to joint control and inspection activities undertaken by two or more Member States (Article 7(g)); it may also issue manuals on harmonized standards of inspections (Article 20).

In 2018 EFCA organized 35 training events, involving 1,496 participants overall. ${ }^{20} \mathrm{EFCA}$ has also delivered training manuals and guidelines, both for $\mathrm{EU}$ and non-EU fishing inspectors, that are available (only for staff members) on its website. ${ }^{21}$

\subsection{Direct Inspections}

Pursuant to Article 19 of Regulation 473, EFCA officials, acting as Union inspectors, may carry out direct inspections in international waters on behalf of the $\mathrm{EU}^{22}$ in accordance with Article 79 of the Control Regulation. According to the latter, the Commission establishes a list of Union inspectors, who may conduct inspections in Union waters and on Union fishing vessels outside Union waters, either in the framework of SCIPs or international fisheries control programmes, where the EU is under an obligation to provide for controls. Therefore, Union inspectors may either be EFCA or Commission staff members.

At present, 18 Union inspectors are members of EFCA. ${ }^{23}$ They act pursuant to the criteria laid down in the Commission Implementing Regulation 404/2011. ${ }^{24}$ During 2018 EFCA's Union inspectors carried out, in the context of the four ongoing JDPs, 176 out of the total of 3,119 sea inspections, corresponding to 5.6 per cent of the total inspections. ${ }^{25}$

\footnotetext{
20 Ibid., 161.

21 https://raining.efca.europa.eu/login/index.php.

22 Another EU authority playing an active role in on-site inspections is e.g. ESMA (see Chapter 15 by van Rijsbergen and Simoncini, section 1.2).

${ }_{23}$ C(2018) 6641 final, Annex to the Commission implementing Decision establishing the list of Union inspectors who may carry out inspections pursuant to Council Regulation (EC) No 1224/2009, Brussels, 15.10.2018.

24 Commission Implementing Regulation (EU) 404/2011 of 8 April 2011 laying down detailed rules for the implementation of Council Regulation (EC) 1224/2009 establishing a Community control system for ensuring compliance with the rules of the Common Fisheries Policy, OJ L 112.

25 EFCA (2019) (note 18 above) 109ff.
} 


\subsection{Inspection Operations Involving Third Countries}

At the Commission's request, pursuant to Article 4 of Regulation 473, EFCA may also assist the EU and Member States in their relations with third parties and regional international fisheries organizations of which the EU is a member, and cooperate with the competent authorities of regional international fisheries organizations regarding the control and inspection obligations of the EU in the framework of working arrangements concluded with such bodies. EFCA may also cooperate with the competent authorities of third countries in matters relating to control and inspection in the framework of agreements concluded between the EU and such third countries.

Currently, EFCA is engaged in four different operations involving third countries: the North East Atlantic Fisheries Commission (NEAFC); the Northwest Atlantic Fisheries Organization (NAFO); the General Fisheries Commission for the Mediterranean (GFCM); and the International Commission for the Conservation of Atlantic Tunas (ICCAT).

The main programming instrument for operations with third countries is again represented by the JDPs ${ }^{26}$ that EFCA adopts with the Member States involved. In the cases of NEAFC and NAFO, two ad hoc JDPs were adopted, whereas GFCM and ICCAT are set up under the framework of already existing JDPs: the Mediterranean for the former, Mediterranean and Black Sea operational plan for the latter.

Within the NEAFC, in 2018 EFCA deployed 16 man-days to participate in joint teams at sea. ${ }^{27}$ Regarding the NAFO, it deployed 93 man-days in joint teams at sea and 22 in mixed teams ashore. ${ }^{28}$ In the case of ICCAT, EFCA participated in 34 joint inspections in the Strait of Sicily from 2 July to 20 August 2018. ${ }^{29}$

\section{CONTROL MECHANISMS FOR EFCA'S INSPECTION ACTIVITIES}

EFCA, in carrying out its inspection-related activities (either directly or indirectly, through coordination or training of national inspectors, or jointly with national and third-country inspectors), is acting upon a delegation from the

\footnotetext{
26 Information about the JDPs regulating operational activities for NEAFC, NAFO, GFCM and ICCAT are available, respectively, at: https://www.efca.europa.eu/en/ content/neafc; https://www.efca.europa.eu/en/content/nafo; https://www.efca.europa .eu/en/content/gfcm; https://www.efca.europa.eu/en/content/iccat.

27 EFCA (2019) (note 18 above) $150 \mathrm{ff}$.

28 Ibid., 147.

29 Ibid., 33.
} 
Table $12.1 \quad$ EFCA's inspection-related tasks and corresponding outputs

\begin{tabular}{ll}
\hline Inspection-related tasks & Outputs \\
\hline $\begin{array}{l}\text { Coordination of and assistance in national } \\
\text { inspections }\end{array}$ & $\begin{array}{l}\text { Adoption of inspection plans and programmes (within the } \\
\text { JDPs) } \\
\text { Participation in joint inspection teams }\end{array}$ \\
& $\begin{array}{l}\text { Preparation of training materials (core curricula, } \\
\text { methodologies) }\end{array}$ \\
$\begin{array}{l}\text { Training and coordination of national } \\
\text { inspectors }\end{array}$ & $\begin{array}{l}\text { Teaching in training courses } \\
\text { Inspection report by Union inspector }\end{array}$ \\
Direct inspections & Adoption of JDPs with the other Member States involved \\
Inspection operations involving third & Participation in joint inspection teams \\
\hline
\end{tabular}

Commission on one side, and, on the other side, from the national competent authorities, which previously used to autonomously exert their own enforcement prerogatives. This implies that there ought to be some mechanisms through which EFCA's activities are controlled. Otherwise, a short circuit in the mechanisms ensuring democracy may occur, either by hindering accountability or transparency upon which the systems of multilevel delegation ${ }^{30}$ are set up. ${ }^{31}$ In the case of EFCA's inspection-related activities, these accountability mechanisms of control can be divided into personal, financial, institutional, judicial and public, as will be illustrated in the following.

\subsection{Personal Accountability}

By personal accountability we refer to the control mechanisms through which the members of an Agency's bodies are appointed and dismissed. They are generally linked to the principal actor (in this case, the Commission), which decides upon their appointment and might remove them before due time if some political discrepancy arises during their mandate.

30 D. Coen and M. Thatcher (2008), 'Network governance and multi-level delegation: European networks of regulatory agencies', Journal of Public Policy, 28(1): 49-71; A. Schout (2018), EU Agencies after 25 Years: a Missed Opportunity to Enhance EU Governance, The Hague, Clingendael Policy Brief.

31 See Chapter 4 on accountability by Brandsma and Moser. 
In the specific case of EFCA, its main units responsible for its activities are the Administrative Board (Articles 32-34 of Regulation 473), the Advisory Board (Article 40) and the Executive Director (Articles 38-39).

Focusing on the four sets of EFCA's inspecting tasks, specific actors who are directly involved in carrying them out will be examined. For example, we may consider the actors involved in the adoption of JDPs, insofar as coordination activities of both national inspections and inspections involving third countries ${ }^{32}$ are foreseen therein. Therefore, it will be appropriate, for our research purposes, to look at how the actors involved in planning and implementing the inspector training activities are controlled, and by whom; in addition, we may consider EFCA staff members appointed as Union inspectors who carry out direct inspections or participate in joint inspection teams.

Regarding the adoption of JDPs, pursuant to Article 13 of Regulation 473, a draft is adopted by the Executive Director in consultation with the Member States concerned. The provision in the third paragraph of Article 13 also states that, if, while preparing a JDP, it emerges that there are not enough means of control and inspection available to achieve the JDP's objectives, the Executive Director has a duty to notify the Member States concerned and the Commission.

As a personal control mechanism, the Executive Director is appointed by the Administrative Board based on her/his experience in the field of the CFP and fisheries controls and inspections, from a list of at least two candidates proposed by the Commission. ${ }^{33}$ The Executive Director's term of office is five years as from her/his appointment, and it can be renewed once by proposal of the Commission, to be approved by two-thirds of members of the Administrative Board. The latter, by the same majority, may also dismiss her/ him, upon request of the Commission or of one-third of its members. The Administrative Board therefore may control how the Executive Director takes her/his relevant decisions regarding JDPs and decide accordingly.

Regarding the actors in charge of adopting EFCA's multiannual work programme - and its annual version - pursuant to Article 24, the multiannual work programme is adopted by the Administrative Board. It includes, amongst other things, the planned training operations for the reference period. The Administrative Board is composed of representatives of the Member States (one per country and an alternate in case of her/his absence) and six members from the Commission. ${ }^{34}$ Its members are appointed based on their expertise in

32 Ongoing JDPs dealing with international cooperation are available at https:// www.efca.europa.eu/en/content/operational-coordination.

33 Art. 39 of Regulation 473.

34 Ibid., Art. 33. 
the field of control and inspections, and their mandate, lasting five years, may be renewed. No provisions on the dismissal of members of the Administrative Board have been made..$^{35}$

Direct inspections are carried out by EFCA's staff members appointed as Union inspectors. Commission Implementing Regulation 404/2011 issued detailed rules for the application of the Union control system as established by the Control Regulation; it provides that the list of Union inspectors is to be adopted by the Commission, drawing on the notifications of Member States and of EFCA. In accordance with Commission Implementing Regulation 404/2011, after the establishment of the initial list, ${ }^{36}$ Member States and EFCA must notify to the Commission yearly any amendment to the list they wish to introduce for the following calendar year, and the Commission must amend the list accordingly. Article 122 of the same Commission Implementing Regulation states that Union inspectors must comply with EU law and, as far as applicable, the national law of the Member State where the inspection takes place (or, in a case where it is conducted outside Union waters, of the flag Member State of the inspected vessel). They are provided with an identification document issued by EFCA (or the Commission in the case where they are appointed by the latter). Nonetheless, there is no clear mechanism of personal control over the actions taken by Union inspectors in the event they do not comply with Commission Implementing Regulation 404/2011 while conducting their inspections. The same lack of mechanisms of personal control can be detected with respect to actions of EFCA's staff members who are involved in joint inspection teams.

Finally, it needs to be mentioned that, on 15 November 2018, a Code of Conduct entered into force; it applies to all persons participating in any of EFCA's activities. The Code is binding (participants in EFCA's activities have to sign a declaration that they will abide by it) and provides a set of standards to be met. In case of violation by an EFCA staff member, the Executive Director 'will take adequate measures in accordance with the Staff Regulations which may include the immediate removal of the EFCA staff member from the activity' (Article 19, Code of Conduct).

\subsection{Financial Accountability}

Financial levers of accountability are forms of controls related to EFCA's budget and how it is employed, according to the political evaluations of the

35 M. Scholten (2014), The Political Accountability of EU and US Independent Regulatory Agencies, Leiden, Brill Nijhoff, 97.

36 Art. 119(1) of Regulation 404/2011. 
institutions entitled to increase or decrease it. The political nexus is here clearly the one that ties financial capacity to the policy scope, which may bring about higher or lower autonomy to the actor under scrutiny. Therefore, its performance will result in a specific political assessment on how its own financial resources might be confirmed, increased or reduced according to the financial authority's overall evaluation.

EFCA carries out its inspection-related activities relying on a budget which, pursuant to Article 44 of Regulation 473, consists of:

(a) a contribution from the EU entered in the general budget of the EU (Commission section);

(b) charges for services provided by EFCA to Member States according to provisions of Regulation 473;

(c) charges for publications, training and other services provided by it.

The control exerted through the budget applies to all four of EFCA's inspection-related activities.

As for the budget coming from the EU, it is granted by the Commission to EFCA through a complex procedure of approval..$^{37}$ In detail, each year the Executive Director draws up a draft statement of estimates of EFCA's revenues and expenditure for the coming financial year, on which basis each year the Administrative Board must produce a further draft statement of estimates, to be forwarded, together with the provisional work programme, to the Commission. The latter, in turn, must forward it to the European Parliament and the Council (the 'budgetary authority') which will finally authorize the appropriations for the subsidy to EFCA. The final budget is then adopted by the Administrative Board and will become final only after the final adoption of the general budget of the EU.

In the event the Administrative Board means to implement any project that may have significant impacts on the approved budget, it must inform the Commission for the budgetary authority to be able to express an 'opinion' (Article 44(12) of Regulation 473) about it.

EFCA's annual report is also subject to the European Court of Auditors' review, pursuant to the provisions of Article 287 TFEU, according to Article 32(2)(b) of Regulation 473.

\subsection{Institutional Accountability}

Institutional accountability mechanisms link EFCA to the other institutions and allow the former to inform the latter (and especially, though not exclu-

37 Cacciatore and Eliantonio (note 2 above) 181. 
sively, its principal, the Commission) about its past, ongoing and future activities - depending on their timing and purpose. Ex ante mechanisms aim to require prior permission to carry out specific actions; ex post mechanisms are those used to account for the way in which the resources are employed and carried out by the institutions entitled to confirm or withdraw political support according to the check's results themselves.

Both ex ante and ex post reporting tools are foreseen regarding the activities of coordination of Member States' inspections, training of inspectors, and assistance and coordination to inspections involving third countries. ${ }^{38}$ More specifically, ex ante and ex post reporting obligations are wide in scope since they cover almost all of EFCA's tasks.

As regards the ex ante reporting tools, we may refer to the previously mentioned multiannual work programme, pursuant to Article 24 of Regulation 473, where the Administrative Board establishes its overall objectives, mandate, tasks, performance indicators and the priorities for each action over a five-year period. In the work programme's latest version, ${ }^{39}$ it is possible to find detailed information regarding the adoption and implementation of JDPs for the current year and for the coming years, covering both information on the coordination of and assistance in national inspections and inspection-related operations involving third countries. ${ }^{40}$ The work programme also provides information on the training activities that are planned for the forthcoming period. ${ }^{41}$

As regards the ex post reporting tools, with specific reference to the JDPs, EFCA, according to Article 15 of Regulation 473, must communicate to the Parliament 'an annual assessment of the effectiveness of each [JDP]', together with an empirical assessment about the possibility that fishing activities are not compliant with applicable control measures. Such annual assessment must be communicated to the Parliament, the Commission and Member States. In addition, upon the European Parliament's request, EFCA's Executive Director is to provide 'all information necessary for the smooth application of the discharge procedure for the financial year in question, as laid down in Article 261(3) of the Financial Regulation'. ${ }^{42}$ The JDPs' annual reports provide accurate infor-

38 The same happens with reference to ESMA's direct inspection powers (See Chapter 15 by van Rijsbergen and Simoncini).

39 EFCA (2018), Programming Document: Multiannual work programme 2019-2020 and Annual work programme 2019, Vigo, European Fisheries Control Agency.

40 Ibid. See, for example, the table on 'Objectives, indicators, expected outcomes and outputs' on p. 34, for in-depth information accounting for the agency's participation in inspections. As regards operations involving third countries, see, for example, the information provided in the table on p. 14, or pp. $18 \mathrm{ff}$.

${ }_{41}$ Ibid., pp. 20-23 and passim throughout the document, for each objective.

42 Art. 45(10) of Regulation 473. 
mation on activities and data both on the joint inspections conducted, in which EFCA's members have also taken part, and on the training courses organized and material produced over the previous year. ${ }^{43}$

Again, with reference to ex post reporting obligations, according to Regulation $473^{44}$ EFCA's Administrative Board must adopt every year the general report on the Agency's overall activity and forward it to the European Parliament, the Council, the Commission, the Court of Auditors and the Member States. The report is not subject to a review clause, ${ }^{45}$ but only to an evaluation clause. ${ }^{46}$

As for inspection activities carried out by EFCA members acting as Union inspectors, Article 123 of Commission Implementing Regulation 404/2011 sets out that they must submit a daily summary on their inspection activities, including specific information listed therein, to the competent authorities of the Member States (i.e. to the flag Member State of the inspected EU fishing vessel). However, there seems to be no such obligation in the legislation for EFCA's staff members who participate in joint inspection teams.

Direct inspections carried out by EFCA members are outside the scope of institutional accountability but, as will be clarified below, this should not be considered to be a gap in the system of controls, especially in those acting ex ante, because of the very nature of inspections, which cannot always be planned in advance so as to be validated by the delegating actors.

\subsection{Judicial Accountability}

By judicial accountability we mean the mechanisms for judicial control of the actions of EFCA, namely in direct actions for annulment under Article 263 TFEU, or through the indirect control provided by the preliminary question of validity under Article 267 TFEU, or in actions for failure to act under Article 265 TFEU and actions for Union liability under Article 340 TFEU.

These mechanisms of control are relevant in the following way: EFCA's enforcement policies contained in the JDPs, its training activities, its investigation activities and final investigation report and its participation in joint teams (in the framework of its cooperation with third countries) could be challenged directly by a vessel master in an action for annulment under Article 263 TFEU, or indirectly through a preliminary question of validity under Article

\footnotetext{
43 See, for example, the latest JDP Mediterranean 12-months report, available on EFCA's website at https://www.efca.europa.eu/sites/default/files/atoms/files/Q4-MED $\% 20$ web\%20report-2018.pdf, for an assessment of the sort of activities accounted for.

44 Regulation 473, Art. 32(2)(b).

45 Scholten (note 35 above) 421.

46 See also Chapter 16 by Timmermans and Chamon on the SRB.
} 
267 TFEU. The failure to undertake those same activities could potentially be the subject matter of an action for failure to act under Article 265 TFEU, brought, for example, by a competitor of a specific vessel master or an NGO concerned with fisheries conservation.

As regards the direct and indirect challenge to EFCA's actions, the starting point is constituted by the requirement of a 'reviewable act', which, for the purposes of an annulment action, concretely excludes from judicial review acts and actions which are not 'intended to have legal effects' ${ }^{47}$ Furthermore, specifically concerning acts of agencies, Article 263 TFEU provides that these can be reviewed if they are 'intended to produce legal effects vis-à-vis third parties'. This limitation entails that EFCA's enforcement policies and any training activities will not be considered a reviewable act before the EU courts because they are not capable of affecting an individual's legal sphere, but constitute a mere statement of objectives or an information-sharing activity.

With regard to inspection reports and activities in the case of direct inspections, which constitute a preparatory step in the decision-making process concluded with a sanction at the national level, in light of the IBM case law, ${ }^{48}$ and specific case law relating to inspection in the field of competition law, ${ }^{49}$ reviewability is also excluded. A fortiori reviewability is excluded for the mere 'participation' of an EFCA official in a joint inspection team, as in this case the contribution of EFCA's officials is 'diluted' in the inspection activity which sees the cooperation of national inspectors and, where applicable, inspectors from third countries. It should also be pointed out that, unlike the case of, for example, competition law, ${ }^{50}$ no prior authorization is required by the applicable legislation either to carry out a direct inspection or to participate in a joint inspection team.

47 Case 22/70 Commission v Council (ERTA) ECLI:EU:C:1971:32, para. 42.

48 In the $I B M$ case, the CJEU held that a measure is reviewable only if it is 'definitively laying down the position of the Commission or the Council in the conclusion of that procedure, and not a provisional measure intended to pave the way for a final decision'. Case 60/81, International Business Machines Corporation v Commission ECLI: EU:C:1981:264, para. 10 .

49 'The investigation procedure referred to ... is not aimed at terminating an infringement or declaring that an act is unlawful, but has the sole object of enabling the Commission to gather the necessary information to check the actual existence and scope of a given factual and legal situation.' Case T-9/97 Elf Atochem SA v Commission ECLI:EU:T:1997:83, para. 22. See for similar considerations concerning an OLAF report, Case T-309/03, Camós Grau v Commission ECLI:EU:T:2006:110, paras. $48-58$.

50 See Art. 20(7) of Council Regulation 1/2003 on the implementation of the rules on competition laid down in Articles 81 and 82 of the Treaty [2003] OJ L 1/1-25. 
The same inspection-related activities could potentially be challenged indirectly through a preliminary question of validity, where there is a national act taken in implementation of them.

Specifically, however, this option materializes only in the case of direct inspections (and possibly in the case of the JDPs): a vessel master could, for example, bring an action against a national measure imposing a sanction and in those national proceedings challenge the validity of an underlying EU measure, such as the inspection report of an EFCA official acting as Union inspector. According to the case law of the CJEU, the range of measures which can be challenged indirectly through a question of validity is wider than those which are amenable to judicial review in direct actions since it is held to include 'all acts of the institutions without exception'. ${ }^{51}$

As regards actions for failure to act, the main hurdle to controlling EFCA's failure to undertake inspection-related activities is the case law of the CJEU on the basis of which failures to act can only be challenged when an EU institution is under a clear obligation to act. ${ }^{52}$ In light of the fact that the applicable provisions do not seem to establish any obligation for Union inspectors to carry out inspections or participate in joint inspection teams, or for EFCA to draft JDPs or provide training, it seems very unlikely that an action for failure to act, brought, for example, by a vessel master who has been subject to an inspection (and who claims that his or her competitor should equally be inspected) or a concerned NGO, would be successful. This is because of the discretion granted to EFCA as to how to enforce the CFP. In addition, it should be pointed out that failures to act by an EU institution or body cannot be the subject matter of a preliminary question of validity. ${ }^{53}$

Finally, as regards EU liability, an action for non-contractual liability is specifically provided for in Article 30 of Regulation 473. On this basis, it might be possible for an applicant fulfilling the liability requirements provided by EU law to request compensation for damage incurred as a consequence of the possible illegality of EFCA's inspection-related activities ${ }^{54}$ However, given the large margin of discretion attributed to EFCA when carrying out

\footnotetext{
51 Case 322/88 Grimaldi $v$ Fonds des maladies professionnelles ECLI:EU:C:1989: 646, para. 8. Case T-193/04 Tillack v Commission ECLI:EU:T:2006:292, para. 80.

52 Case T-95/96 Gestevisión Telecinco v Commission ECLI:EU:T1998:206, para. 71; Case T-127/98 UPS Europe v Commission ECLI:EU:T1999:167, para. 34.

53 Case C-68/95 T Port GmbH \& Co. KG v Bundesanstalt für Landwirtschaft und Ernährung ECLI:EU:C:1996:458, para. 53.

54 See e.g. Case T-309/03 Camós Grau v Commission ECLI:EU:T:2006:110, paras. $75-81$, in which a report by OLAF terminating an anti-fraud investigation was held to be an act capable of giving rise to EU liability.
} 
such inspection-related activities, it is unlikely that any claim for liability will be successful. ${ }^{55}$

However, it should be pointed out that, while an applicant could potentially bring an action for the damage incurred as a consequence of an inspection activity by EFCA, this avenue is not open in the case of a lack of action, as actions for liability as a consequence of a failure to act can only be brought where an institution has infringed a legal obligation to act. ${ }^{56}$

\subsection{Public Accountability}

By public accountability we mean all those mechanisms allowing for a direct interaction between EFCA and the public, so that the latter can be kept updated on the former's activities and take an active part in them. These forms of control are mostly concerned with transparency mechanisms, also aiming to open the decisional process to all interested parties, but they may also be ex post tools used to make an agency account for how resources were employed and policies carried out (see Chapter 9 on transparency by Buijze).

As regards transparency and access to EFCA's documents, Regulation 1049/2001 on public access to all EU documents applies to documents held by EFCA. Therefore, according to Article 41(5) of Regulation 473,

[d]ecisions taken by the Agency pursuant to Article 8 of Regulation (EC) No $1049 / 2001$ may give rise to the lodging of a complaint to the Ombudsman or form the subject of an action before the Court of Justice, under Articles 228 and 263 of the Treaty on the Functioning of the European Union (TFEU).

Moreover, '[t]he Commission shall have full access to all information collected by the Agency. The Agency shall furnish any information and an evaluation of that information to the Commission at its request and in the form specified by it' (Article 43(1)), and to the Member States only insofar as they are directly concerned by specific activities carried out by EFCA and by the documents delivered in association with those activities.

Because the publication of the multiannual work programme (ex ante) and of the annual report (ex post) also serve the purposes of transparency vis-à-vis the public, public accountability covers all the actions accounted for therein:

55 This conclusion is based on the established case law of the CJEU, according to which, in order to incur liability, an EU institution needs to have 'gravely and manifestly disregarded the limits of its discretion'. Case C-352/98 P Bergaderm and others $v$ Commission ECLI:EU:C:2000:361, para. 43.

56 Case T-196/99 Area Cova SA and others $v$ Council and Commission ECLI:EU: T2001:281, para. 84 . 
inspections (EU and third countries) coordinated by the EFCA, and training activities. As regards direct inspections, although it is not possible for the public to freely access information on a specific inspection (i.e. to access an inspection report and related documents), aggregated data on the overall number of inspections carried out regarding specific operations are available in EFCA's reports (both the annual general report and the JDP-specific reports). It is also possible to know how many inspections out of the total carried out report suspected (or ascertained) infringements, how the joint teams were composed and the types of infringements detected during the control operations. ${ }^{57}$

With regard to training activities, it is also worth mentioning that the Agency has a dedicated online e-learning platform, ${ }^{58}$ where registered people can access information on the training calendar and more.

\section{CONCLUSIONS: EFCA'S INSPECTION ACTIVITIES - A BLIND SPOT IN THE SYSTEM OF JUDICIAL CONTROLS?}

Drawing on the analysis carried out above, Table 12.2 summarizes the types of controls available for each of the inspection-related activities of EFCA.

From this overview, it appears that, except for the mechanisms of financial control, which cover all four inspection-related functions of the Agency, the other four types of controls (personal, institutional, judicial and public) are lacking in some cases.

More specifically, activities of coordination and assistance in national inspections - which represent a large share of the tasks which EFCA carries out daily - entail some control phases either through the 'political' relationships between the actors involved, who personally account to other institutions for the decisions made regarding such activities, or through the institutional link which allows for both ex ante and ex post checks of, respectively, programmes and reports; moreover, they are exposed to public control insofar as these programmes and reports are mostly public and available on EFCA's website. However, because of either the largely political nature of these activities (in the case of the JDPs) or the 'diluted' and non-formalized nature of the share of EFCA's action (in the case of the participation of EFCA coordinators in national joint inspections), it is not likely that a form of judicial control will be available to interested parties. While this gap is not problematic in the case

57 See, for example, the latest JDP Mediterranean 12-months report (note 43 above), or that related to the JDP Baltic Sea, at https://www.efca.europa.eu/sites/default/files/ atoms/files/2018\%20-\%20THE\%20BALTIC\%20SEA\%20JOINT\%20CAMPAIGN \%20-\%2012M\%20REP\%20WEB.pdf.

58 Available at https://training.efca.europa.eu/login/index.php. 
EFCA's inspection-related tasks, with corresponding outputs and control mechanisms

\begin{tabular}{|c|c|c|c|c|c|c|}
\hline & \multirow{2}{*}{ Outputs } & \multicolumn{5}{|c|}{ Control mechanisms } \\
\hline & & Per & Fin & Ins & Jud & Pub \\
\hline \multirow[t]{2}{*}{$\begin{array}{l}\text { Coordination of and assistance } \\
\text { in national inspections }\end{array}$} & $\begin{array}{l}\text { Adoption of inspection plans and } \\
\text { programmes (within the JDPs) }\end{array}$ & $\sqrt{ }$ & $\sqrt{ }$ & $\sqrt{ }$ & & $\sqrt{ }$ \\
\hline & Participation in joint inspection teams & $\sqrt{ }$ & $\sqrt{ }$ & $\sqrt{ }$ & & $\sqrt{ }$ \\
\hline \multirow[t]{2}{*}{$\begin{array}{l}\text { Training and coordination of } \\
\text { national inspectors }\end{array}$} & $\begin{array}{l}\text { Preparation of training materials } \\
\text { (core curricula, methodologies) }\end{array}$ & & $\sqrt{ }$ & $\sqrt{ }$ & & $\sqrt{ }$ \\
\hline & Teaching in training courses & & $\sqrt{ }$ & $\sqrt{ }$ & & $\sqrt{ }$ \\
\hline Direct inspections & Inspection report & & $\sqrt{ }$ & & $\sqrt{ }$ & $\sqrt{ }$ \\
\hline \multirow[t]{2}{*}{$\begin{array}{l}\text { Inspection operations involving } \\
\text { third countries }\end{array}$} & $\begin{array}{l}\text { Adoption of JDPs with the other } \\
\text { Member States involved }\end{array}$ & $\sqrt{ }$ & $\sqrt{ }$ & $\sqrt{ }$ & & $\sqrt{ }$ \\
\hline & Participation in joint inspection teams & $\sqrt{ }$ & $\sqrt{ }$ & $\sqrt{ }$ & & $\sqrt{ }$ \\
\hline
\end{tabular}

of the JDPs as the lack of judicial accountability is compensated for by a strong presence of other forms of controls which are, in fact, more appropriate to the political nature of this activity, the same cannot be said for the participation of EFCA coordinators in national joint inspections. In this case, the lack of judicial accountability constitutes a true gap in the control system as the other forms of controls are ill-suited for bringing to light certain possible illegalities in the inspection activities (such as possible fundamental rights violations), for which a court seems to be the most adequate forum.

Almost the same applies for the inspection activities involving third countries in that most provisions are the same as those related to the coordination activities: this holds true with regard to the actors in charge of taking decisions in both fields and to the documents - and related procedures of adoption - through which these operations are planned and reported. Here specific mention must be made of the JDPs, which are the main tool for planning both EU and extra-EU joint operations. Finally, again the political nature of the JDPs and the low level of institutionalization of EFCA's activities in joint inspection teams, stand in the way of a form of judicial control over these activities. As a consequence the same considerations made above with respect to the gaps in judicial accountability apply to this task as well.

An even lighter regime of controls characterizes the training and coordination of inspectors' activities, which benefit from an institutional and public control system (besides the financial one), but to which no EFCA member has 
to personally respond. In other words, no direct and personal responsibility is acknowledged regarding the training of inspectors, but it is EFCA as a body that accounts for them ahead of the other institutions, the public and the EU financial authority. As a mere information dissemination activity, naturally no judicial control is provided for these tasks. Nonetheless, this does not look like an accountability gap insofar as such activities do not imply any binding decision addressed to trained inspectors, and the purely 'political' assessment through institutional accountability seems the most appropriate form of control.

Finally, direct inspections, which are the most sensitive and tricky function with which EFCA is entrusted when it comes to inspections - because they entail direct enforcement of EU laws and an immediate impact on the regulatees, with likely judicial outcomes - appear at first glance as the least covered function in terms of control. In carrying out these functions EFCA only undergoes financial and judicial controls. Nonetheless, even judicial control is only present in a limited way since only the indirect route of the preliminary question of validity is available to applicants; the failure to undertake an inspection cannot, either directly or indirectly, be subject to judicial control, and the liability route, though theoretically open, is in fact impracticable. Hence, it can be concluded that a worrisome gap in the control system can be identified with respect to this task.

To conclude, while financial accountability is confirmed to be a crucial means for the EU's oversight activity on EFCA, ${ }^{59}$ and one supposed to counterbalance gaps in other forms of 'political' control, judicial control is almost entirely lacking with reference to all EFCA's inspection-related tasks, except, to some extent, for direct inspections. Crucially, and as a matter for further research, the participation of EFCA staff members in joint inspection teams, both in the EU and abroad, seems to be a complete blind spot for the purposes of judicial control. Given its relevance for the purposes of potential fundamental rights violations and the difficulties in allocating responsibility for such violations, it is essential to continue research into the practical operation of the joint inspection systems in the process of European integration.

\footnotetext{
59 Cacciatore and Eliantonio (note 2 above).
} 